\title{
Specific Forms of Interpretation of Cultural Heritage for Tourists with Various Forms of Disability
}

DOI 10.18267/pr.2021.krn.4816.6

\author{
Liběna Jarolímková ${ }^{1}$ - Kateřina Chaloupková ${ }^{2}$ - Jiří Vaníček ${ }^{3}$ \\ ORCID iD: 0000-0001-8502-5220a1 , 0000-0001-7625-3475a², 0000-0003-3468- \\ $4087 a^{3}$ \\ jaro@vse.cz, katerina.chaloupkova@vse.cz, jiri.vanicek@vse.cz \\ 1, 2, 3 Faculty of International Relations, Department of Tourism, Prague University of \\ Economics and Business \\ Prague, Czech Republic
}

\begin{abstract}
The article analyses the development of new technologies in tourism for disadvantage persons and focuses on their application in the interpretation of cultural heritage in the Czech Republic. It briefly presents a survey of methods of cultural heritage interpretation for people with disabilities (PwD) and outlines the trends and challenges in accessible tourism using ICTs.

The article presents the results of a follow-up research focused on the technological aspects of the interpretation of cultural heritage for individual groups of visitors with different types of disabilities. The survey was conducted in the period 2018-2020 using a combined method of a desk research and structured interviews. The result of the data analysis was the identification and detailed characteristics of the specific needs of all PwD groups. The field research method was used to determine the current state of ICT use to make interpretation available for PwD. Key findings: ICT is a useful tool for solving specific needs of PwD, but the level of its utilization is still very low in the Czech Republic.
\end{abstract}

Keywords: interpretation, cultural heritage, people with disabilities, ICT, accessible tourism

JEL Classification codes: O33, O35, Z32

\section{INTRODUCTION}

The basic long-term trend of the tourism market is its growth and democratization. When the period before the COVID-19 pandemic situation is considered, the growth in the tourism demand can be seen in the growing number of travels, higher travel expenses and wider diversification of the demand. Tourism is increasingly accessible for more and more people with different interests and demands, people from different parts of the world and from heterogeneous social background. There is a growing number of requests to offer travel experience to anybody irrespective of their physical limits, health disability or age. Providers of tourism services respond to these demands with the effort to dismantle any barriers and promote tourism services and products among other segments of clients.

According to World Health Organization about $15 \%$ of the world's population lives with some form of disability (WHO, 2018). This global estimate for disability is on the rise due to population ageing and the rapid spread of chronic diseases. The increasing number of PwD in population is supposed to account also for an increase in the number of PwD among travellers. Although it stated in the World Bank report that employment, level of income and thus also the purchasing power of PwD is lower in average than among people without disabilities (World Bank, 2020), the number of PwD participating in tourism is growing. This is a result of various 
general programmes focused on supporting the quality of PwD life and software supporting tourism accessible for all. In addition to barrier-free access necessary for implementation of a journey, PwD should have access to as many services and experiences as possible. This requires adjustment of even accompanying services to the needs of travellers with diverse disabilities.

Exploration and learning are an important motive for travelling. As the head of the charity fund for visually impaired people says, the travelling increases self-reliance and self-esteem, it gives people a feeling of freedom and their own choice (Vejvodová, 2020). A range of various interpretation methods is prepared for familiarization of a visitor with the values of the site visited.

The Tourism Department of the Faculty for International Relations at the Prague University of Economics and Business was a coordinator of the international Erasmus+ project "Methodology of Interpretation of European Cultural Heritage through Attractions in Tourism" (implemented in 2017-2020). The project examined the current methodology of cultural heritage interpretation in tourism, both tangible and intangible heritage: architecture, music, fine arts, religious monuments, folk traditions, and gastronomy. As mentioned above, interpretation methods must be applied with respect to the needs of individual segments of visitors. The crucial characteristic features are the country of origin and cultural background of the visitor, their motivation and depth of interest in learning and age. Physical and mental abilities of the visitor must be considered too.

With the growing emphasis on the inclusion of PwD in tourism, it is also desirable to adapt the methods of interpretation of the segment of PwD visitors. This article presents the summary results of an independent follow-up research carried out in connection with the solved project. The aim of this research was to identify the specific needs of people with various forms of disability in the interpretation of cultural heritage and evaluate the options and state of implementation of ICT in this area.

\section{LITERATURE REVIEW}

A meta-analysis on the topic has not been carried out, as the topic is narrowly specific. A comparable study dealing with the topic could not be traced. On the contrary, there is a huge amount of professional scientific articles and current studies on the topic of tourism for all, ICT in tourism, and inclusion of PwD in tourism and in society (Gillovic \& McIntosh, 2020; Huang \& Lau, 2020). These topics have been processed systematically for decades; from the most recent works, the theoretical framework of this chapter was created.

Tourism for all includes concepts like social, responsible and accessible tourism. Its aim is to create such conditions that all people would be able to participate in tourism, which means that nobody would be expelled from consumption due to health or social barriers ("Tourism for all - Internal Market, Industry, Entrepreneurship and SMEs - European Commission", 2021) (Travel for all, 2020). Social tourism is based on solidarity and support to economically and socially disadvantaged segments and on making tourism services available to these segments (low-income families, seniors, youth, or people with health disabilities) (ISTO, 2020). It covers activities organized by NGOs, by employers for their employees, by the government, local administrations, charity organizations, etc., which will help socially disadvantaged people overcome the barrier and travel. Accessible tourism (barrier-free tourism) adjusts physical accessibility of attractions, creates barrier-free environment. It includes activities improving accessibility of tourist destinations, facilities and services and facilitates their comfortable and safe utilization to all potential clients without any additional assistance or necessity of additional adjustments (Buhalis and Darcy, 2011) (Zorková, Vaníček, 2017). Taleb Rifai, Secretary General of the UNWTO, highlighted the role of accessible tourism as a central 
element of any responsible and sustainable tourism policy: "It is both a human rights imperative, and exceptional business opportunity. Above all, we must come to appreciate that accessible tourism does not only benefit persons with disabilities or special needs, but it also benefits us all." (ENAT, 2010).

The information and communication technologies (ICT) play a crucial role in overcoming the several travel constraints that people with disability face when planning and undertaking a trip. Technologies assist people with disability with mental, sensory, voice and speech, neuromusculoskeletal and movement functions (Rodriguez Moreno, 2016). ICT include technologies, systems, activities and processes involved in the display, processing, storage and transmission of information and data by electronic means. It intervenes in all successive actions in the process of supply, demand and consumption of travel services. ICTs help to raise knowledge of destinations, promote the offer to tourists and enable consumers to participate in rating, sharing and experiencing systems. The basic pillar of ICT, enabling its existence and use, is the telecommunications and Internet infrastructure. The access, its speed and the means by which the connection is made are key for the transfer of information via the Internet (Jarolímková, Chaloupková 2018).

In general, computers and mobile phones are the most widely used tools by the public. Widespread and affordable broadband access is one of the means of promoting a knowledgebased and informed society. Thank to rising Internet accessibility as well as its decreasing cost, $89 \%$ of EU households had an Internet access in 2018. Ten years ago, this number was only $60 \%$ (Eurostat, 2019). In addition, the number of individuals who used a website or an app to arrange a travel service has been increasing in the past decade. In 2018, the share of European individuals (aged 16-74) who booked the accommodation online was $19 \%$ (from 44 $\%$ in Luxembourg to $3 \%$ in Cyprus and $5 \%$ in Czechia) (Eurostat, 2019).

According to Statista, in 2017 around 13,2 \% of the U.S. population had some type of disability (problems with mobility, hearing, vision or cognition). Disability is more common among older individuals (65 years and older), who use the Internet and ICT less than younger people. 95 $\%$ of Internet users between 25 and 34 years of age use the Internet every day, but only 76 $\%$ in the age $55+$ use the Internet daily (Statista, 2016).

\section{METHODOLOGY}

The chapter examines a very narrow topic, which is an intersection of four very wide topics: tourism - cultural heritage interpretation - specific needs of PWD - ICT. The survey was conducted in the period 2018-2020. Various methods of data collection and processing were used in the completing of the chapter. The methods of a desk research and structured interviews were used for identification and characterization of 4 main PwD travellers' groups:

- PwD with limited mobility.

- PwD with impairment of senses - Hard-of-hearing impairment or deaf visitors.

- PwD with impairment of senses - Visual impairment and blind visitors.

- PwD with mental disabilities.

Application of modern technologies in tourism has been elaborated in the previous research (Jarolímková, Chaloupková, 2018). Its results have been supplemented by current desk research (professional articles and studies from 2015-2020), which provided an overview of the assistive technologies of using ICT for the disabled people during travel.

The topic of interpretation of cultural heritage was researched comprehensively within the international project coordinated by our workplace (2017-2020) (Jarolímková and MIECAT 
project team, 2020). An overview of the specific needs of individual segments of PwD in the field of interpretation of cultural heritage was created based on a compilation of the results of studies on general needs of PwD and structured interviews with representatives of 6 Czech organizations focused on PwD carried out during December 2019. The setting of interpretation methods for PwD and their evaluation were investigated by a field research and data analysis in information systems for PwD at selected important Czech monuments carried out during the period November 2019-April 2020.

\section{RESULTS AND DISCUSSION}

\section{Trends and challenges in accessible tourism using ICT.}

As more and more aspects of life are moving to online environment, there has been a shift in the use of mobile Internet, which allows to be online all the time and almost everywhere. In this connection, we speak about so-called Smart Travel, a new era of travelling thanks to the development of IT. When it comes to mobile apps, we can witness a growing dependence of tourist destinations and tourists on new forms of ICTs (Chaloupková, Jarolímková, 2018), which benefit from virtual reality, gamification, and geo-location. These apps show service providers the past behaviour and individual preferences of their users and potential clients. The technological shift towards Smart tourism is huge and the tourism industry will be pioneer in utilization of IT even in future (Gretzel, 2015). Live-videos and video-advertisements are currently considered to be standard, compared to static billboards and poster forms (Socialreport.com, 2018).

According to the European Commission, more than 80 million people are affected by some form of disability - sensory, physical, intellectual or mental. Nevertheless, less than $10 \%$ of websites in Europe are accessible for persons with disabilities (European Commission, 2019). In this context, importance of web accessibility must be mentioned (European Commission, 2019).

Ways to help these people contemporary can be different. For deaf or people with hearing problems, text could be followed by captions, subtitles. Those who are blind, can use screen reader, a digital audio file as podcast. Colour blind would welcome text and images with significant contrast ratio. There are systems which can help dyslexic people avoid and correct mistakes. For unstable users with stress injury or with cognitive disability are helpful keyboard navigation and predictable (easy to read content) navigation; etc. ICT is not always perceived as a positive tool. Many professionals talk about ICT as a barrier to social relations for disabled youth (Marshall, Kendall, 2009).

PwD are participating more and more frequently in tourism activities because of their growing level of economic and social integration. In EU, accessible tourism market is estimated at approximately $27 \%$ of the total population and $12 \%$ of the tourism market (UNWTO, 2016).

\section{Assistive technology}

PwD need certain assistive devices to work fully on the computer. These devices help them improve physical and mental functions and facilitate them communication with the computer. That can be used not only by PwD, but seniors using the Internet can find them useful as well.

People with visual impairment need special devices or programs like Speech-to-Text software or software to magnify the text. There is a special touch keyboard, monitor showing the text in the Braille, etc. People with hearing impairment can search for information quite well. Thanks to the development of IT, there are new and improved devices, which facilitate communication between those with and without disabilities (e-mails, SMSs, chats). Watching the news, these people can use various hearing aids - the news is often interpreted 
simultaneously into the sign language or are accompanied with subtitles. Persons with heavy physical disability, when they are almost immobile and work on the PC, can use e.g. a trackball or joystick, sip and puff systems. People with mental disabilities and learning disorders form another category. They usually use specialized dictionaries and spell-checkers, Intel-Readers or Speech-to-Text software.

\section{Social media, access to social networks and travel blogs}

Social networks used daily by the broad public have become the most important digital media. The highest level of social networks utilization is in the USA. More than 246 million Americans (70 \%) visited or founded their account there in 2019. The most common activities on these platforms are posting photos, sending private messages, comments or giving "likes" to the content (Clement, 2020). Regularly used platforms on the American market are Facebook, Instagram, Snapchat, YouTube, Pinterest, WhatsApp, Twitter, Tumblr, WordPress, Yelp, TripAdvisor, LinkedIn etc.

The mainstream social media such as Facebook, Instagram or Twitter have created tools that differently abled people use to have full access to these websites without any trouble. The Facebook invests into video captioning and Artificial intelligence to make the website a leader in tech accessibility. Its automatic photo-captioning tool describes objects in photos to blind people. New face recognition features help people with vision loss to know more about who is in their photos. Facebook also has several closed captioning features to help people who are hearing impaired: closed captions for videos on Facebook via text file upload, automatic video captioning for ads and Pages in the US, and real-time captioning in Facebook Live broadcasts (Facebook @accessibility, 2020). In 2018, the Instagram introduced two new improvements to make it easier for people with visual impairments to use the app. The Instagram estimates more than $\mathbf{2 8 5}$ million people in the world who have some visual impairment. Therefore, it has prepared an automatic alternative text so that these people can hear descriptions of photos through screen reader when using the Feed, Explore and Profile. Furthermore, the app has created custom alternative text to add a richer description of photos for uploading a photo. People using screen readers will be able to hear this description (Instagram, 2018). The Twitter also gives an option to compose a description of images, so the content is accessible to more people, including blind or low vision (Twitter, 2020). Although generally the websites are constantly updated, the special tools that were created for PwD are often forgotten and not updated in accordance with these websites, making them unusable (Griffith University, 2017).

In the market there are many portals sharing experience of travellers and professional providers of travel packages. One of the most popular travel webs all over the world is TripAdvisor, which obtains a forum for travellers with disabilities, containing an accessibility checklist for hotel accommodation, travel recommendations about rights of travellers with disabilities, their travel insurance, air travel with medicaments, etc. This community offers more than 1.500 topics (Tripadvisor, 2020). Like the TripAdvisor, but for accessible and inclusive travel, is an online guide "Travel for All," incorporating a community and providing detailed accessible travel information, discussion forums and a blog included. Travellers with accessibility needs have access to trustful and verified information to plan, book and experience travel with confidence (Travel for all, 2020). Trying to copy the TripAdvisor for PwD, the app "Access Earth" provides clear and separate information about places - if the place is barrier-free, how wide the doors are, if there are private bathrooms available, etc. They can get turn-by-turn navigation to a place using their preferred travel app (apps Uber and Lyft are integrated) (Access Earth, 2020).

\section{Smart maps}

App with geo-locating data provides information about barrier-free regions suitable for people on wheelchairs. People with a limited mobility must consider their journey from two points of view. The first one is the journey to the destination itself. The Tube Map in London by Mapway 
is a good option. The other one is accessible locations. The application Wheelmap provides and summary of wheelchair accessible hotels, landmarks and attractive places. It can be downloaded from the Apple, OS or Google Play. All apps have their limits. The Wheelmap contains information from European countries and towns (Wheelmap, 2020). As well as any common traveller, wheelchair travellers need information about public toilets and parking lots for PwD. The interactive map WheelMate with information about more than 35 thousand places from 45 countries can help with this. Even though almost 17 thousand people have downloaded this app, some of them complain about an insufficient number of data (WheelMate, 2020).

Not only wheelchair travellers can explore the destination thanks to the app called Disway. developed in the Czech Republic. It shows them an overview of barrier-free locations, including advice and comments from other users and contains gamification (Disway, 2020).

\section{Voice technology}

A further development of other digital media focuses on the voice and their spread in broad public can be predicted. Artificial intelligence such as Amazon Alexa, Google Assistant and Apple HomePod, have been developed for the consumer market for a long time not only for the purpose of being spread among users with visual impairment and so the user satisfaction has been confirmed (socialreport.com, 2018). Broader public has been getting familiar with article podcasts, which they can listen to anytime, in case they prefer listening to reading. Thus, there is a massive use of voice technology and at the same time increasing amount of content accessible to visually impaired people.

As mentioned above, social networks Facebook, Instagram, Twitter and many others have offered a technological solution in form of a screen reader for people who lost the vision. Amazon Alexa technology as a part of smart household can interact with a voice, replay music, create a list of tasks, set up alarms, stream podcasts, replay audiobooks, provide information about weather, traffic, sport and news in real time (Amazon Alexa, 2020). A specific voice app for travellers with hearing impairment is RogerVoice, which transforms mobile phone calls into text format. Deaf people can easily read telephone messages from their partners on the screen. This software distinguishes a speech includes voice conversion into several languages and so it also helps people with translation in a foreign country (RogerVoice, 2020).

\section{Video technology}

A so-called Life streaming has become a part of daily life of the public. Approximately $80 \%$ of consumers would prefer watching a live video made by a given brand than reading a blog and $82 \%$ would prefer live video to a written form of social websites upgrade (DeMers, 2017). Socalled live video-talks (e.g. app "Be my Eyes") also help blind persons. Mentioned app is based on the principle of a friendly approach to PwD, where volunteers describe the picture.

Unlike the others, the deaf must deal with two disabilities during their travels - they do not hear and there is a lack of sources of information in sign language. The sign language is specific in each country and is not easy to understand. The Czech team wanted to change it and in 2018 they created the first travel guide application DeafTravel which was launched in 2019. This app interprets some video guides into the international sign system, which is artificially created for communication of the deaf from all over the world (DeafTravel, 2020).

\section{Virtual and augmented reality in tourism}

One can see the virtual reality as an epochal technology, thanks to which people with mobility limitations can explore foreign destinations and visit historical and cultural sites. Almost all travellers all over the world could experience - due to covid-19 lock down - the feeling when physical travelling is limited. Many providers of tourism services (in particular, hotel owners and historic and cultural attractions) have stated with digitalization of their products. The 
intermediators of these travel also paid attention to virtual versions of trips, activities or tours. Examples are TripAdvisor's Viator - project called \#RoamFromHome, creating over 100 virtual experiences, that range from home cooking courses to digital walks around city centres or landmarks (Viator.com, 2020), AirBnB, Headout, and CityMe through the StayCurious account on Instagram. Virtual travellers pay a participant fee for these experiences. Up to $80 \%$ of the money raised in this way go for the support of SMEs, which were most hit by the coronavirus outbreak.

Spread of technological innovations in the form of virtual reality influenced perception of tourist destinations. Virtual 3D world offers sightseeing of destinations to potential visitors and opportunities for new forms of tourist experience-oriented communication with target markets and organizations of destination management (Huang \& Backman \& Backman \& Chang, 2015). The aim of this technology is to create sense experiences for visitors, which would involve as many senses as possible - sight, touch, hear, smell and even taste. Nevertheless, the user needs specific hardware equipment for such perception, e.g. a display placed on the head, earphone base, etc.

Virtual reality, mobile phones and its applications and games use haptic technology, for more comfortable control. A typical feature for this technology is extreme sensitivity to touch, with the recognition of the touch degree, resp. what force you push. The most used map portal Mapy.cz in the Czech Republic made an internet map available for blind people and covering a whole world. The so-called haptic maps are the result of a unique technology that generates data for tactile maps based on visual maps (Wolf, 2019).

\section{Automatization and Robotization}

Current professional discussions reflect the current development in the field of automatization and robotization and concern creation of new models in industries. The "Industry 4.0" in Germany and France including Internet networks 5G covers utilization of new technical opportunities such as artificial intelligence, robots, sharing of networks and work with so-called big data. Although the number of robots used in households is increasing in the field of cleaning and entertainment, assistive robots for elderly or handicapped people remain a rarity now and it seems for the foreseeable future (Richter, 2017). Nevertheless, the future belongs to these solutions in daily lives of handicapped people and on their journeys both real and those virtual ones.

In these days, robot design is less about the hardware and more about developing algorithms. As technology improves, it is becoming a powerful tool to influence positively the lives of PwD. Robotic systems are used as tools in healthcare as prosthetic limbs, robotic exoskeletons, assistant robots and brain-to-machine interfaces. While these assistive technologies are improving, people with disabilities are also helping scientists to more precisely understand how to teach machines to learn, which is helping to improve their lives and robot design (McSweeney, 2019).

\section{Cultural heritage interpretation}

Cultural tourism can be defined as a form of tourism whose participants mainly want to learn about the cultural heritage and culture of the respective country and its citizens. The intention to participate in some form of cultural activity is present in approximately $57 \%$ of all multiple day journeys of international tourists; in about $39 \%$ of journeys cultural activities are the dominating reason for travelling. Culture is a significant factor in the life of the civil society and significantly helps its integration. It contributes to the development of intellectual, emotional, and moral level of every citizen and functions as an educative element (Richards, 2018). Several studies show that knowledge of the culture of other spaces is one of the main motivations that drive tourists. Exploiting cultural heritage through tourism activity becomes a 
fundamental means for the development of places where this heritage is located (UNWTO, 2018). Cultural tourism has a positive economic and social impact, it launches and strengthens identity, helps to conserve cultural heritage, it facilitates harmony and understanding among people, supports culture and helps to further development of tourism. Cultural tourism has several goals that must be fulfilled within the context of sustainable development, such as preservation of cultural sources, correct interpretation of cultural heritage, authentic experience of visitors and stimulation of revenue from cultural sources. It also must consider the impact of tourism on villages and regions and the achievement of economic and social benefits (McKercher, Du Cros, 2002). The European Commission set priorities in its policy to promote cultural heritage (European commission, 2018).

It is necessary to provide quality interpretation of cultural heritage. The leitmotif of cultural tourism is getting familiar with the place visited. The exploration involves not only learning about the facts, but also understanding the context of cultural and historic events and their influence on the past and current life of local inhabitants. During their stay, visitors build their attitude to the destination and local people, their culture and cultural heritage. It is therefore, in the interest of both the destination and visitor that the cultural heritage is correctly interpreted (Vaníček, Jarolímková, 2019).

\section{Forms of cultural heritage interpretation}

As the results based on our investigation have showed, interpretation is provided in different ways. The choice of the form is mostly influenced by the characteristics of the monument, goals of the interpretation and technical, financial and organizational possibilities of the provider. It should also respect specific needs and preferences of individual segments of visitors. A combination of different methods and tools of interpretation offered is usually used and so a visitor can choose the one, which meets their needs and current preferences best.

Interpretation of cultural heritage has two basic forms - personal and non-personal. In personal interpretation, the interpreter meets the visitor directly. It can be a guided tour, shows and workshops with a lecturer, living history, etc. This form of interpretation is considered most efficient and is preferred by majority of visitors. According to the survey more than $80 \%$ respondents across all age groups prefer this type. Personal interpretation offers an opportunity to respond flexibly to the needs and interests of visitors and the timely situation; it is live, up to the date, authentic and persuasive. However, it has high demands on the qualification of interpreters and demanding is also its organization. It has its limits, as the capacity, language competence of the interpreter and time accessibility of the service. Adjustment of personal interpretation to the needs of PwD is possible thanks to high flexibility; however, the interpreters need to be trained specially for communication with PwD.

Non-personal interpretation uses different technical aids and media, e.g. printed materials, interpretation panels, audio-visual tools, digital media and projection in virtual reality. The visitor can choose his or her own pace of the visit, as well as the depth and content of the information, which he will use. The advantage of non-personal interpretation is its almost unlimited accessibility (information can be obtained almost anywhere and anytime). Its limit is little flexibility and difficulty with ongoing changes of the content. The visitor lacks a personal contact with a live representative of the destination. Non-personal interpretation is popular among visitors who prefer individual programme, independence, piece and personalized pace of the tour.

ICT can be beneficial also in interpretation for PwD as they can facilitate a tour of places, which are inaccessible due different barriers, or they can facilitate specific communication. Interpretation is provided mostly at the attraction itself, that means in-situ. Modern technologies bring the opportunity to interpret cultural heritage in an interesting and quality way even ex-situ, which is very important especially for people with limited mobility. 
The most often used methods of interpretation are: guided tours, printed materials, interpretation panels, audio-guides, multimedia guides/mobile apps, video-spots, virtual reality, augmented reality, visitors/interpretation centres and exhibitions, shows, presentations, tastings, concerts, workshops, working lists, living history, dramatization, gamification. Other forms of spreading the information sometimes connected with interpretation are discussions, conferences, educative programmes.

Development of society and tourism market obviously also influences the approaches to the interpretation of cultural heritage. Very important is e.g. the process of globalization, changes of the demographic and socio-cultural structure of the society, development of information and communicational technologies and deepening process of digitalization (Jarolímková and MIECAT project team, 2020).

Basic trends in the interpretation of cultural heritage are changes in the content of the information (shift from artistic and historic content of the message to message in a broader social, geographical and historical context), interactivity, haptic elements, utilization of technologies in interpretation, during interpretation, gamification.

\section{Potential of interpretation methods for implementation of ICT for PWD}

Technologies have been used in interpretation since the first computers, TV screens were installed, and the first audio-guides and information kiosks with static screens were introduced. Today, however, the scope of tools is dynamically growing and touch screens, audio-visual systems, projection technology and video-mapping, and mobile equipment with access to the Internet, applications, multimedia, virtual reality, and QR codes are available. New media open new indefinite opportunities and possibilities and result in the shift from static text panels at exhibitions to visualisation and interactivity (Šobáňová, 2014). Some authors (Davies 2014, Činčera a kol., 2018) speak about the birth of "digital interpretation". The main advantage of efficient use of technologies is the possibility to adjust the interpreted content by displaying various levels of information and language versions. This can help to answer one of the most important current challenges - individualization (Koutoura, 2014).

When planning interpretation for PwD segments it is necessary not only convert the information into a digital form, but it is often necessary to adjust the content into a form accessible and understandable for PwD (to simplify the message, use different words, increase visualization, etc.). Printed interpretation materials in a common form are not suitable for some PwD segments. But they can be transformed into a digital form and adjusted for communication with PwD.

Interpretation panels are most often permanently placed in the terrain near important sites. Their goal is to attract the visitor to the site and to provide basic information and so to help the visitor understand the importance of the place and provoke the interest and curiosity leading to searching for further information. Panels can be placed independently and separately near the monuments (e.g. memorial tables on the facades of houses) or they can be placed along a heritage trail and their information follows the previous one.

Information panels can be accessible also in a digital form on the websites of their administrator. There might be a word-by-word transcription of the text from the panel, or the description on the website is more detailed. In some case there is only a digital form of information and in the terrain, there is placed only an QR code (Quick Response code) instead of an interpretation panel. The place of the panel, its size or design is often unsuitable for $\mathrm{PwD}$. The solution to this is conversion of the information into a digital form and adjustment of its form for communication with PwD. Adjustment of the content is usually easy. 
Audio-guide is a presentation of a guide recorded in the device, which can be operated by a visitor him/herself according to his/her interest. The recording contains a spoken word, which can be completed with some other sounds (music, "sounds of the street", etc.). Besides the presentation of a guide, it can contain also interviews with experts, elderly witnesses, timely recordings e.g. of old radio broadcasting) or dramatization. There are usually three levels of comprehensiveness and the visitor can choose the level and thus amount of information they are ready to listen to and of course their own pace of the tour. Audio-guides can be offered in many language versions; it is only a question of how much money the management is willing to invest into it. The visitor can borrow the device, or they can download the recording into their mobile phones.

Another option are stationary kiosks, where a visitor can play the recording from an in-built tape-recorder. At some exhibitions, earphones are available and so other visitors are not disturbed. A disadvantage is a limited capacity of earphones. A disadvantage is technical discomfort - the use of earphones is uncomfortable for some visitors; reproduction of the voice is not always clear. An audio-guide is popular especially with visitors to museums and exhibitions, often also for individual sightseeing tours of a town. Regarding PwD, an audioguide is suitable for people with limited mobility, as they will appreciate their own pace of the tour. Another advantage is that the content is easily adjustable to visitors with visual impairment or with mental disability.

Videos in interpretation are common in the form of films, slide shows, video mapping, projection on water, etc. The presentation can be complemented with photos and videosequences. Film and photo recordings are appealing to visitors and can facilitate various topics, e.g. documentation of historic moments, traditional feasts, moments from the life of an important personality, recordings of interviews with witnesses. Information and details, which a visitor cannot experience because they are not well accessible, can be shown with a film. Films are often used at the beginning of an exhibition as a lead-in tool; videos showing traditional handicrafts are performed on the screens placed at different places of an exhibition. Films at the end of an exhibition, mostly bibliographical documentaries give further details to the interpretation.

If videos are used for PwD with limited mobility, some changes in the lay out of the room are necessary - easily accessible seats, zones for wheelchairs). Video equipped with a translation into the sign language is necessary for people with hearing impairment. A multimedia guide is based on more advanced technologies as it combines the above-mentioned forms of interpretation. It represents a higher level of interpretation.

Mobile applications represent another alternative to a tourist guide. They provide their users with a wide range of information about monuments and destinations. Apps are usually linked with maps and a calendar of events. The information can easily be updated. They work online and are interactive, so they can locate the user and respond to the change of user's position. Most of the apps can work off-line. The content is at the border between the information service, interpretation, promotion, sales promotion and game. It is a modern medium, which is used by more than $40 \%$ of visitors on holiday (Haušková, 2013).

The use for PwD is similar as in the case of audio-guides, videos and multimedia guides. The tour can be undertaken in one's own pace. The content can easily be adjusted to different needs of PwD.

Virtual reality is a 3D environment created with a computer. It is based on the scan of a real environment, which can be experienced thanks to special software and reading device. The visitor is moving in a virtual space and feels to be its part, the picture responds to the visitor's activity. The visitor gets a very authentic experience and idea of the interpreted place (Gosalia, 2018). 
The use of virtual reality is useful especially for places, which cannot be visited in person. These are inaccessible places, places with difficult access for people with limited mobility or with visual impairment, places with limited capacity of visitors.

Augmented reality is a virtual reality complemented with elements created with the computer. In the interpretation of cultural heritage, $A R$ is used to simulate original equipment of the interiors, reconstruction of unpreserved parts of structures, or a person of a virtual guide. The use of augmented reality is beneficial for monuments, which have been destroyed or lost (e.g. archaeological sites, ruins of castles, etc.). Augmented reality visualizes the original monument (e.g. digital reconstruction of the ancient temple in Olympia). Other technical solutions, e.g. 3D projection for basic visual idea or video mapping (e.g. reconstruction of a church in Belgium) can be used for the same purpose (Kubů, 2019).

Visitor's/interpretation centres and exhibitions offer modern multifunctional space with permanent interactive items familiarizing visitors with cultural heritage. These centres are designed as barrier-free and have the best prepared methods for interpretation for PwD.

Gamification: games are designed as contests, quizzes (the visitor is searching for answers to questions), quests (riddles, the visitor tries to find references in the field to solve these riddles), rally (a game in the field, when the visitor must solve various tasks in the field), assembling models, etc. All these activities help to learn and understand the destination by playing. (Blohm, 2013, Bulencea, 2017). The game can be based on printed materials, it can use mobile apps or downloaded in the tablet. It is usually not difficult to adjust the game for PwD.

The presented study is an initial overview of the situation in the Czech Republic. Research into the extension of different methods of interpreting cultural heritage for PwD will continue. The current survey shows that in the future it would be desirable to prepare a more detailed benchmarking analysis of the use of ICT tools in the interpretation for PwD in Germany, in Belgium and Spain, which have more advanced solutions to the situation. Another necessary direction is the standardization of information on the accessibility of services for PwD travellers and the design of a model for planning interpretation for PwD for the most visited types of monuments.

\section{CONCLUSION}

Evaluation of ICT tools used for facilitation of cultural heritage interpretation to disadvantage persons is an intersection of three very wide topics - tourism, needs of PwD and ICT. The contribution of tourism to create an inclusive society requires the adoption of new approaches and strategies that promote the accessibility of tourism destinations, allowing all people, regardless of their health condition, to enjoy tourism experiences.

Trends of tourism development and demographic development indicate that travelling of PwD will grow and PwD will become an important segment of travellers. PwD have specific needs when they travel and when they participate in the interpretation of cultural heritage. Destination should therefore reflect these needs in their offer of interpretation methods.

Information about travelling of PwD are provided by different stakeholders with a lack of coordination:

- Destination (Czech Tourism, regional organisation of destination management) prepare general information about accessibility of services in the destination. Most information is focused on persons with limited mobility, other PwD are neglected.

- Tourist destinations, monuments: it is estimated that more than a half of tourist destinations and attractions in the Czech Republic includes information for PwD in 
their information materials. Again, mostly for people with limited mobility. Information for other PwD segments is very rare.

- Open, collectively created sources are information/interpretations created by travellers. Information is practical and fully respond to the needs of PwD. However, they are created by fans without knowledge of interpretation principles.

- There are foundations supporting selected programmes for the improvement of the life of PwD. Since 2006, Vodafone Foundation has supported more than 500 projects and divided CZK 200 million among projects, which significantly improve lives of people. The app Signslate, helping to people with hearing impairment gathers interpreters into the sign language. Whenever a deaf person needs, they can use their service in real time. (Nadace Vodafone, 2020). Foundation Světluška (Lightning bug) supports travelling and hiking of people with visual impairment.

Evaluating the interpretation methods for PwD we made the following conclusions. Interpretation of cultural heritage uses various methods of personal and non-personal interpretation. Utilization of ICT for higher quality interpretation is a current trend. Even though the range of methods is wide, and utilization of ICT might really help to make interpretation more accessible for everyone, we can witness that in real life only rarely. ICT is a useful tool for solving specific needs of PwD, but the level of its utilization is still very low. There are three reasons for this situation. Underestimation of the PwD segment of visitors and little or no knowledge of their needs. High costs of interpretation using ICT and low return of investments, other financial priorities and little experience with using ICT. Little pressure from the demand side for the improvement. Interpretation adjusted for the needs of PwD is considered a pleasant luxury service. Nevertheless, its non-existence does not discourage people from the visit. Most PwD who like travelling are used to integrating with public and are satisfied with the services offered, even though they cannot fully use all services. PwD themselves are not always convinced that investments into this field should be a priority and they prefer subsidies for improvement of conditions for their daily activities.

All stakeholders in the tourism industry should consider travelling of PwD as a great challenge. The development in providing better tourism services meeting the needs of PwD so far is promising, but still very slow and does not reflect the great potential of this segment. The chapter contributes to promotion of the knowledge of ICTs that can help to adapt the interpretation of cultural monuments to PwD.

\section{REFERENCES}

Access Earth (2020). What is Access Earth? Retrieved 15 January 2021, from: https://access.earth/

Amazon Alexa. (2020). Alexa Voice Service. Retrieved 29 January 2021, from: https://developer.amazon.com/en-US/docs/alexa/alexa-voice-service/api-overview.html

Blohm, I. \& Leimeister, J.M. (2013). Gamification. Business \& Information Systems Engineering, 5(4), 275-278. https://doi.org/10.1007/s12599-013-0273-5

Brizard, T., Derde, W., \& Silberman, N. (2007). Basic Guidelines for Cultural Heritage Professionals in the Use of Information Technologies. How can ICT support cultural heritage? Stockholm: The Interactive Institute AB. Retrieved 29 January 2021, from: http://www.enamecenter.org/files/documents/Know-

how\%20book\%20on\%20Cultural\%20Heritage\%20and\%20ICT.pdf 
Bulencea, P. (2017). How to create immersive storytelling experiences for your tourism attraction. Gamification in Tourism. Retrieved 5 January 2021, from: http://www.gamificationin-tourism.com/blog/

Buhalis, D., \& Darcy, S. (2011). Accessible Tourism: Concepts and Issues. Bristol: Chanel View Publications. ISBN-13:978-1-84541-161-9.

Clement, J. (2020). Social media usage in the United States - Statistics \& Facts. Statista. Retrieved 2 December 2020, from: https://www.statista.com/topics/3196/social-media-usagein-the-united-states/

Činčera, J., Medek, M., \& Lupač, M. (2018). Příroda 2.0? Využití digitálních médií pro terénní interpretaci přírodního dědictví. Masarykova univerzita. Retrieved 5 January 2021, from: https://munispace.muni.cz/library/catalog/view/993/3087/748-1/\#preview

Davies, J. (2014). On-site Digital Heritage Interpretation. Current uses and future possibilities at World Heritage Sites. Durham: Durham University. Retrieved 1 February 2021, from: https://www.academia.edu/15642304/Onsite_Digital_Heritage_Interpretation_at_World_Heri tage_Sites_Current_uses_and_future_possibilities

DeafTravel (2020). Retrieved 5 January 2021, from: https://deaftravel.guide/

DeMers, J. (2017). 7 Social Media Trends That Will Dominate. Forbes. Retrieved 2 February 2021, from: https://www.forbes.com/sites/jaysondemers/2017/12/27/7-social-media-trendsthat-will-dominate-2018/\#52c2effe25fb.

Disway (2020). Retrieved 5 January 2021, from: https://www.disway.org/

ENAT (European network for accessible tourism) (2010). Národní rada osob se zdravotním postižením CR, Praha ČR, TRIANON. Athena na cestách. Přístupný cestovní ruch v kostce. Třinec: Kazuist, 2010.

European Commission (2019). Digital inclusion and web accessibility. European Commission: Shaping Europe's digital future. Retrieved 2 February 2021, from: https://ec.europa.eu/digitalsingle-market/en/news/digital-inclusion-and-web-accessibility-brochure

European Commission (2018). Initiative 5 Tourism and heritage. Retrieved 12 December 2020, from: https://ec.europa.eu/culture/content/tourism-and-heritage_en

Eurostat (2019). Digital economy and society statistics - households and individuals. Eurostat: Statistics explained.Retrieved 5 January 2021, from: https://ec.europa.eu/eurostat/statisticsexplained/index.php?title=Digital_economy_and_society_statistics_-

_households_and_individuals\#Services_ordered_from_other_individuals_via_the_internet

Facebook page @accessibility. (2020). Retrieved 20 December 2020, from: https://www.facebook.com/accessibility/

Gillovic, B., \& McIntosh, A. (2020). Accessibility and Inclusive Tourism Development: Current State and Future Agenda. Sustainability, 12(22), 9722. https://doi.org/10.3390/su12229722

Gloucester Cathedral. (2020). Accessibility Guide for Gloucester Cathedral. Retrieved 2 December 2020, from: https://www.accessibilityguides.org/content/gloucester-cathedral

Gosalia, A. (2018). Experience augmented reality together with new updates to ARCore. Google. $\quad 2$ Detrieved 2020, from: https://www.blog.google/products/arcore/experience-augmented-reality-together-newupdates-arcore/

Gretzel, U., Sigala, M., Xiang, Z. \& Koo, Ch. (2015). Smart tourism: foundations and developments. Electronic Markets, 25(3), 179-188. ISSN 10196781. https://doi.org/10.1007/s12525-015-0196-8 
Griffith University (2017). New social network bringing the disabled community together. Griffith University. Retrieved 16 December 2020, from: https://projectopendoors.org/2017/09/11/new-social-network-bringing-the-disabledcommunity-together/

Hájková, V. (2006). Specifika pro handicapované klienty služeb cestovního ruchu. Ministerstvo pro místní rozvoj ČR, Praha. Retrieved 16 December 2020, from: https://www.mmr.cz/getmedia/dec21386-b551-48e4-bbad-113ab984a35e/GetFile10.pdf

Haušková, B. (2013). Aplikace Alois Nebel přináší nové příběhy, turistům slouží jako průvodce. Retrieved 20 December 2020, from: https://www.novinky.cz/vase-zpravy/clanek/aplikacealois-nebel-prinasi-nove-pribehy-turistum-slouzi-jako-pruvodce-40144675

House of European History (2020). Museum for all. Retrieved 16 December 2020, from: https://historia-europa.ep.eu/en/general-information

Huang, L., \& Lau, N. (2020). Enhancing the Smart Tourism Experience for People with Visual Impairments by Gamified Application Approach through Needs Analysis in Hong Kong. Sustainability, 12(15), 6213. https://doi.org/10.3390/su12156213

Huang, Y. Ch., Backman, K. F., Backman, S. J., \& Chang, L. L. (2016). Exploring the Implications of Virtual Reality Technology in Tourism Marketing: An Integrated Research Framework. International Journal of Tourism Research. 18(2), 116-128. https://doi.org/10.1002/jtr.2038. ISSN 10992340.

ISTO (2020). Who we are - Organisation internationale du tourisme social. Retrieved 18 December 2020, from: https://isto.international/who-we-are/

Jarolímková, L., \& Chaloupková, K. (2018). Application of modern technologies in marketing tools in tourism. Recenzovaný sborník 13. mezinárodní konference Aktuální problémy cestovního ruchu. Vysoká škola polytechnická Jihlava, 134-143. ISBN 978-80-88064-36-7

Jarolímková, L. and MIECAT project team (2020). Interpretation of European Cultural Heritage in Tourism. Prague University of Economics and Business, Oeconomica Publishing House Prague 2020, ISBN 978-80-245-2391-0. Retrieved 9 January 2021, from: https://oeconomica.vse.cz/publikace/interpretation-of-european-cultural-heritage-in-tourism/

Koutoura, A. (2014). Edutainment in Museums: A Tool for Disseminating Knowledge. Maastricht University. Retrieved 11 December 2020, from: https://www.academia.edu/10377338/Edutainment_in_Museums_a_Tool_for_Disseminating _Knowledge

Kubů, P. (2019). Trendy v interpretaci kulturního dědictví (architektura). Diplomová práce, VŠE v Praze.

LVR-Landesmuseum Bonn (2020). Retrieved 29 January 2021, from: https://landesmuseumbonn.Ivr.de/en/service/barrierefreiheit/barrierefreiheit_1.html

Masters, D. (2012). Content is not enough: Using motivational techniques to improve participation and learning in mobile apps. In: Interpret Europe Conference in Pisa. Retrieved 2 January 2021, from: http://www.interpret-europe.net/fileadmin/news-tmp/ieevents/2012/presentations/DavidMasters-Pisa2012-1.pdf

Marshall, C. A., Kendall, E., Banks, M. E., \& Gover, R. M. S. (Eds.). (2009). Praeger perspectives. Disabilities: Insights from across fields around the world. $1,61-70$. The experience: definitions, causes, and consequences. Praeger/ABC-CLIO. ISBN 9780313346040

McKercher, B., \& Du Cros, H. (2002). Cultural tourism: the partnership between tourism and cultural heritage management. New York: Haworth Hospitality Press. ISBN 07-890-1106-9. 
McSweeney, K. (2019). Robot Design Helps People with Disabilities. Now. Northrop Grumman: The intersection of technology, innovation \& creativity. Retrieved 9 January 2021, from: https://now.northropgrumman.com/robot-design-helps-people-with-disabilities/

Moptil (2020). Open the window to history. Retrieved 11 December 2020, fromhttps://moptil.com/

Nadace Vodafone (2020). Technologie pro společnost. Tlumočení do znakového jazyka kdykoliv a kdekoliv. Retrieved 11 December 2020, from https://www.nadacevodafone.cz/programy/technologie-pro-spolecnost/aktualniprojekty/signslate.html

Národní památkový ústav (2020). Premiéra virtuální prohlídky Švihova pro hendikepované. Retrieved 29 January 2021, from: https://www.hradsvihov.cz/cs/pro-media/18035-premieravirtualni-prohlidky-svihova-pro-hendikepovane

Neumann, P. (2006). Economic Impulses of Accessible Tourism for All. NeummannConsult. Germany. $\quad$ Retrieved 24 January 2021, from: https://www.ferdamalastofa.is/static/files/upload/files/peter_n.pdf.

Richards, G. (2018). Cultural Tourism: A review of recent research and trends. Journal of Hospitality and Tourism Management, 36, 12-2. ISSN 1447-6770. https://doi.org/10.1016/j.jhtm.2018.03.005

Richter, F. (2017). Let the Robot Do the Cleaning. Statista: Infographics. Retrieved 29 January 2021, from: https://www-statista-com.zdroje.vse.cz/chart/9089/worldwide-personal-robotsales-forecast/

Rodrígez, M. (2017). Tecnologias de informacion y comunicacion para el turismo inclusivo. Revista Facultad de Ciencias Economicas: Investigacion y Reflexion, 26(1), 125-146. ISSN 01216805. https://doi.org/10.18359/rfce.3142

RogerVoice (2020). Retrieved 2 January 2021, from: https://rogervoice.com/en/

Socialreport.com (2018). 7 Digital Marketing Trends That Will Own 2019. Retrieved 3 January 2021, from: https://www.socialreport.com/insights/article/360000663006-7-DigitalMarketing-Trends-That-Will-Own-2019

Statista (2020). Active social media user penetration in the Asia Pacific region in January 2020, by country. Statista.com. Statista Research Department. Retrieved 4 January 2021, from: https://www-statista-com.zdroje.vse.cz/statistics/255235/active-social-media-penetration-inasian-countries/

Statista (2018). Social media usage in Europe. Statista.com. Retrieved 24 January 2021, from: https://www.statista.com/topics/4106/social-media-usage-in-europe/

Statista (2016). United States: daily internet usage 2016, by age group. Statista.com. Statista Research Department. Retrieved 15 January 2021, from: https://www-statistacom.zdroje.vse.cz/statistics/348247/daily-internet-usage-age-group-united-states/

Šobáňová, P. (2014). Muzejní expozice jako edukační médium. 1. Díl Př́stupy k tvorbě expozic a jejich inovace. Olomouc: Univerzita Palackého v Olomouci. 364 s. ISBN 978-80-244-4302-7.

Topographie des Terrors (2020a). Informationen in Leichter Sprache. Retrieved 15 January 2021, from: https://www.topographie.de/historischer-ort/leichte-sprache/

Topographie des Terrors (2020b). Videos in Gebärdensprache. Retrieved 29 January 2021, from: https://www.topographie.de/historischer-ort/leichte-sprache/

Travel for all (2020). Retrieved 15 January 2021, from: https://travelforall.guide/ 
Tourism for all - Internal Market, Industry, Entrepreneurship and SMEs - European Commission (2021). Retrieved 15 January 2021, from: https://ec.europa.eu/growth/sectors/tourism/business-portal/accessibility_en

Tripadvisor (2020). Traveling With Disabilities Forum. TripAdvisor. Retrieved 15 January 2021, from: https://www.tripadvisor.com/ShowForum-g1-i12336-Traveling_With_Disabilities.html

Twitter (2020). Help center. Retrieved 29 January 2021, from: https://help.twitter.com/en/using-twitter/picture-descriptions

UNWTO (2018). Tourism highlights 2018 edition, UNWTO, Madrid. eISBN: 978-92-844-19876

UNWTO (2016). World Tourism day 2016. Tourism for all - promoting universal accesibility. Good Practices in the Accessible Tourism Supply Chain. UNWTO. ISBN 978-92-844-1812-1

Vaníček, J., \& Jarolímková, L. (2019). Kulturní cestovní ruch v České republice. Oeconomica. 106 s. ISBN 978-80-245-2345-3

Vejvodová, I. (2020). Tipy na výlety bez bariér po celém Česku. Tisková zpráva CzechTourism. Retrieved 2 January 2021, from: https://www.czechtourism.cz/pro-media/tiskove-zpravy/tipyna-vylety-bez-barier-po-celem-cesku/

Viator (2020). Find amazing things to do. Anytime, anywhere. Retrieved 4 February 2021, from: https://www.viator.com/

Weber, J. (2014). Gaming and Gamification in Tourism. 10 Ways to Make Tourism More Playful. Best Practice Report. In: Digital Tourism Think Tank. Retrieved 12 February 2021, from: http://thinkdigital.travel/wp-content/uploads/2014/05/Gamification-in-Tourism-Best-

Practice.pdf

Wheelmap (2020). Find wheelchair accessible places. Retrieved 4 February 2021, from: https://wheelmap.org/

WheelMate (2020). Google Play. Retrieved 12 February 2021, from: https://play.google.com/store/apps/details?id=com.novasa. wheelmate\&hl=cs

WHO (2018). World Health Organization: Disability and health. Retrieved 4 February 2021, from: https://www.who.int/news-room/fact-sheets/detail/disability-and-health

World Bank (2020). Disability Inclusion. Retrieved 2 December 2020, from: https://www.worldbank.org/en/topic/disability

World Heritage Visitor Centre Regensburg (2020). Retrieved 2 December 2020, from: https://tourismus.regensburg.de/en/about-regensburg/unesco-world-heritage/worldheritage-visitor-centre.html

Wolf, K. (2019). Haptické mapy od Seznamu již pokrývají celý svět. Lupa.cz. Retrieved 2 January 2021, from: https://www.lupa.cz/aktuality/hapticke-mapy-od-seznam-cz-jizpokryvaji-cely-svet/

Zorková, D. \& Vaníček, J. (2017). Accessible Tourism from the Point of View of Tourism Providers and Clients. Studia Turistica 8(1), 67 - 78. VŠP Jihlava, ISSN 1804-252X 